\title{
The majority of human CD3 epitopes are conferred by the epsilon chain
}

\author{
Alan Tunnacliffe, Carina Olsson, and Antonio de la Hera \\ Basel Institute for Immunology, Grenzacherstrasse 487, 4058 Basel, Switzerland \\ Key words: transgenic mouse, soluble CD3, T cell activation, $T$ cell antigen receptor
}

\begin{abstract}
Transgenic mouse $T$ cells expressing the human $\mathrm{CD}_{\epsilon}$ chain bind the majority (29/36) of monoclonal antlbodies (mAbs) speciflc for human CD3. A proportion of these mAbs are also able to recognize lsolated $\mathrm{CD} 3 \epsilon$ in a soluble, recombinant form. Thus, $\mathrm{CD} 3 \epsilon$ can confer most $\mathrm{CD} 3$ epitopes on the TCR - CD3 complex, but many determinants may require assembly of the complex for their formation. A number of mAbs did not recognize $\epsilon$-transgenic $T$ cells and probably need other CD3 subunlts for binding. CD3-specific mAbs from each of the three groups defined here, as well as mAbs directed agalnst the TCR $\alpha \beta$ heterodimer, are all able to actlvate $T$ cells. Therefore mAb attachment at several different sites on the TCR - CD3 complex can give rise to actlvation signals. This suggests that the cross-linking function of mitogenic antibodles may be their most signiflcant property, rather than the perturbation of a particular 'functional epltope'.
\end{abstract}

CD3 is a cluster of transmembrane proteins (termed $\gamma, \delta$, and $\epsilon)$ associated with antigen receptor on the $T$ cell surface (TCR-CD3 complex) $(1,2)$. Most CD3-specific monoclonal antibodies (mAbs) have mitogenıc propertıes (3) and, largely as a result of this finding, CD3 is thought to trigger T cell activation subsequent to antıgen recognition. However, the large number of CD3-specific mAbs that have now been characterized can show marked variation in their ability to elicit certan $T$ cell activation phenomena (4). Some of these effects may be attributable to the avidity of the antibody for its target $(5,6)$ or to antibody isotype (reviewed in ref. 7), but in other cases it has been suggested that the site of mAb binding may be important (4), giving rise to the concept of 'functional' CD3 epitopes. It is expected that a functional epitope corresponds to one or more 'physical' epıtopes. Therefore, mappıng antıgenıc determınants on CD3 may define functionally important regions of the complex. Although several studies implicate multiple epitopes on the TCR - CD3 complex (8,9), little information on their localization has so far been obtained. Standard cross-blocking techniques on $T$ cells have been largely unınformatıve sınce most CD3-specific mAbs tested seem to block each other at least partially $(10-12)$. We have therefore taken two new approaches to mapping $\mathrm{mAb}$ binding sites within the CD3 complex, using (i) transgenic mice whose T cells express the human $\mathrm{CD} 3 \epsilon$ gene, and (ii) recombinant soluble forms of $\operatorname{CD} 3 \gamma, \delta$, and $-\epsilon$.

Transgenic mice which carry the human $\mathrm{CD} 3 \epsilon$ gene were found to express the transgene in thymocytes and peripheral $T$ cells, and to deliver the human $\mathrm{CD}_{\epsilon} \epsilon$ protein to the cell surface as part of the mouse TCR - CD3 complex (A. Tunnacliffe et al., in preparation). When cultured spleen $T$ cells from the transgenic mice were stained with a panel of CD3-specific mAbs, it was found that most (29/36) antibodies were positive, although of varyıng intensity (Fig 1, Table 1) TCR $\alpha \beta$ - or TCR $\gamma \delta$-specific mAbs were negative, as expected. All CD3-specific mAbs stained human peripheral blood $T$ cells equally well and were negative on non-transgenic, littermate mouse T cells The 145-2C11 mAb, specific for mouse CD3e (13), showed the converse staınıng pattern (Fig. 1). These results demonstrate that the majority of CD3 epitopes recognized by available CD3-specific mAbs are conferred by the epsilon chain. To test whether some eptopes rely for their formation on assembly of human CD3 $\epsilon$ into the mouse TCR-CD3 complex, we assayed for binding of mAbs to isolated CD3e in the form of a soluble recombinant molecule

Recombinant proteins have been generated which consist of the extracellular domain of either human $\operatorname{CD} 3 \gamma,-\delta$, or $-\epsilon$ linked to mouse $C_{x}$. These soluble molecules-termed $\gamma-x, \delta-x$, and $\epsilon-x$-are produced and secreted by myeloma-derived transfectant clones, and are immunopreciptable by rat antisera raised against purified CD3 subunits (14). Among the mAbs which stained $\epsilon$-transgenic T cells, 18 were able to immunoprecipitate surface-labelled, natıve CD3 (Figs 1 and 2a; summarized in Table 1). These mAbs were tested against metabolically labelled $\epsilon-\boldsymbol{x}$, and as controls, $\boldsymbol{\gamma} \boldsymbol{x}$ and $\boldsymbol{\delta}-\boldsymbol{x}$ : a typical experıment is shown in Fig. 2(b-d). Six mAbs, including the widely used UCHT1 and Leu4 antibodies, bound $\epsilon-\mathcal{x}$ (Fig. 2d, Table 1) and therefore recognize $\mathrm{CD} 3 \epsilon$ alone in the native TCR-CD3 complex.

Correspondence to A. Tunnacliffe, as above

Transmitting editor. C. Martınez-A 


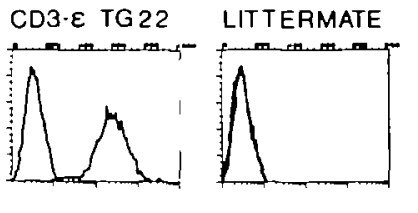

HUMAN

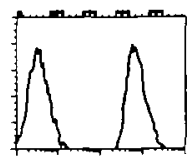

UCHT 1
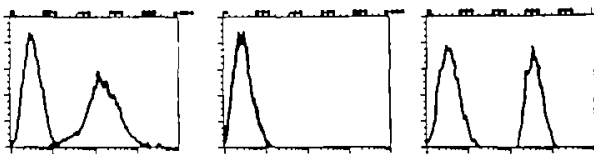

VIT3
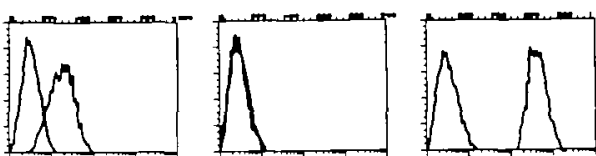

$12 \mathrm{~F} 6$
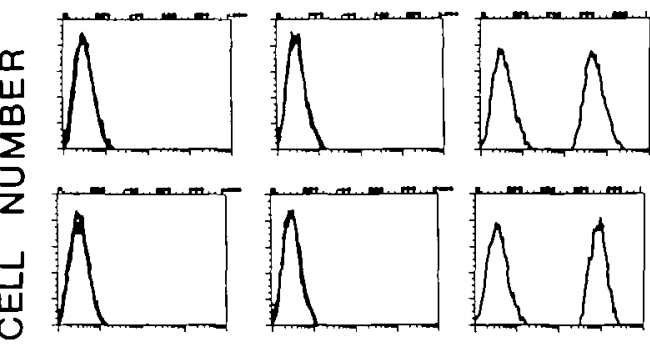

38.1

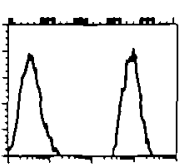

BMA032
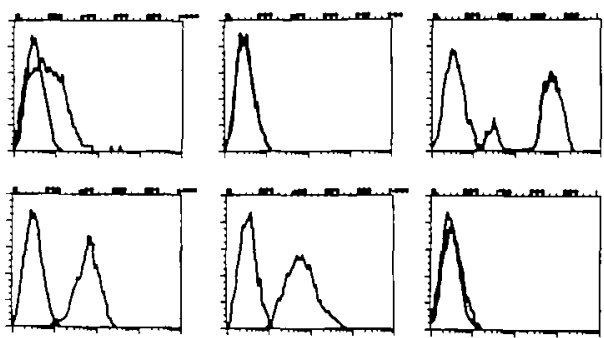

LOG GREEN FLUORESCENCE
Flg. 1. Staining of $\mathrm{CD} 3_{\epsilon}$ transgenc mouse, control littermate, and human $T$ cells by CD3-specific monoclonal antibodies Results are depicted as curves of fluorescence distribution on a logarthmic scale The left histogram in each panet represents the binding of normal mouse serum as background control Details of the construction of transgenic mice carrying the human $C D 3 \notin$ gene will be published elsewhere (A. Tunnacliffe et al., in preparation). Mice (of the TG22 lıne) carryıng multiple copies $(>10)$ of the transgene were analysed here. Spleens were obtained from ether TG22 mice or control littermates that did not carry the transgene and single cell suspensions were prepared from these organs Human peripheral blood was from Kantonsspital (Basef) blood bank donors, and mononuclear cells were isolated using Ficoll-Hypaque (Pharmacia, Uppsala, Sweden). Cells were maintaned in 'complete medium', consisting of RPMI 1640 medium supplemented with $2 \mathrm{mM}$ glutamıne, $10 \mathrm{mM}$ HEPES, $50 \mathrm{mM}$ 2-mercaptoethanol, and $10 \%$ heat-inactivated foetal calf serum (GIBCO, Paisley, UK). To prepare $T$ cell lines, cells $(2 \times 105 / \mathrm{ml})$ were cultured in the presence of anti-CD3 mAb and $50 \mathrm{U} / \mathrm{ml}$ recombınant interleukın 2 (rlL2) (Hoffmann-La Roche, Basel) for 4 days. Then the cells were washed to remove unbound antboody and expanded in complete medium containing $50 \mathrm{U} / \mathrm{ml}$ rlL2 2 by spliting the cultures $\left(10^{5}\right.$ cell $\mathrm{s} / \mathrm{ml}$ ) every second day. T cell lines used in the experiments reported here were cultured for 12 days The procedure for immunofluorescence surface staning of cells has been described (27). Fhuorescern-conjugated goat anti-mouse or ant-rat $\lg$ (Southern Biotechnology) was used as a second step reagent for human CD3-specific mAbs. $145-2 C 11$ was directly conjugated with fluorescein. Quantitation of the surface immunofluorescence on $10^{4}$ vable cells was performed with a FACScan instrument (Becton-Dickınson, Mountain View, CA, USA) equipped with a four decade logarthmic amplifier.
Table 1. Summary of CD3 epitope mapping data

\begin{tabular}{|c|c|c|c|c|c|}
\hline $\begin{array}{l}\text { CD3 } \\
\text { mAb name }\end{array}$ & $\begin{array}{l}\text { Workshop no. } \\
\text { or reference }\end{array}$ & Isotype & $\begin{array}{l}\text { Human } \\
\text { PBL }\end{array}$ & $\epsilon$ transgenic & $\epsilon-x$ \\
\hline \multicolumn{6}{|l|}{ Group 1} \\
\hline UCHT1 & 471 & G1 & ++ & ++ & + \\
\hline VIT3b & 478 & $\mathrm{G} 1$ & ++ & ++ & + \\
\hline G19-4 1 & 484 & G1 & ++ & ++ & + \\
\hline SK7/Leu4 & 492 & G1 & ++ & ++ & + \\
\hline MEM-57 & T096 & G2a & ++ & ++ & + \\
\hline CD3-4B5 & T103 & G1 & ++ & ++ & + \\
\hline \multicolumn{6}{|l|}{ Group II } \\
\hline$\times 35-3$ & 472 & G2a & ++ & ++ & - \\
\hline VIT3 & 477 & $M$ & ++ & ++ & NP \\
\hline $\begin{array}{l}\text { BMA030 } \\
\text { (BW264/56) }\end{array}$ & 482 & G2b & ++ & ++ & - \\
\hline CLB-T3/3 & 489 & G2a & ++ & ++ & - \\
\hline CRIS7 & 490 & G2a & $+t$ & $t+$ & ND \\
\hline YTH12.5 & 491, T100 & G2b (rat) & ++ & ++ & - \\
\hline$F 111-409$ & T099 & Gi & ++ & ++ & - \\
\hline CLB-T3 4/2a & ref 7 & G2a & ++ & ++ & - \\
\hline TR-66 & ref. 20 & G1 & ++ & ++ & - \\
\hline WT32 & ref. 21 & G2a & ++ & ++ & - \\
\hline OКТ3 & ref. 22 & $\mathrm{G} 2 \mathrm{a}$ & ++ & ++ & - \\
\hline SPV-T3b & ref 23 & G2a & ++ & ++ & ND \\
\hline $11 D 8$ & ref. 23 & G1 & ++ & ++ & ND \\
\hline XIII-141 & 473 & G2a & ++ & + & NP \\
\hline XIII-46 & 474 & G2a & ++ & + & NP \\
\hline$x|1|-87$ & 475 & $\mathrm{G} 2 \mathrm{a}$ & ++ & + & NP \\
\hline $12 \mathrm{~F} 6$ & 483, T094 & $\mathrm{G} 2 \mathrm{a}$ & ++ & + & - \\
\hline T3/RW2-8C8 & 487 & $\mathrm{G} 2$ & ++ & + & NP \\
\hline T3/RW2-4B6 & 488 & $\mathrm{G} 2 \mathrm{~b}$ & $+t$ & + & - \\
\hline OKT3D & T098 & $\mathrm{G} 1$ & ++ & + & - \\
\hline M-T301 & T101 & G1 & ++ & + & NP \\
\hline SMC2 & T104 & $M$ & ++ & \pm & NP \\
\hline F101.01 & ref. 16 & G1 & ++ & + & ND \\
\hline \multicolumn{6}{|l|}{ Group III } \\
\hline 381 & 476 & $M$ & ++ & - & NP \\
\hline $\mathrm{T} 3 / 2 \mathrm{~T} 8-2 \mathrm{~F} 4$ & 486 & G1 & ++ & - & NP \\
\hline BL-AB & T093 & G1 & ++ & - & NP \\
\hline T10/B9 & T095 & $M$ & ++ & - & NP \\
\hline MEM-92 & T097 & $M$ & ++ & - & NP \\
\hline$M-T 302$ & T102 & G1 & ++ & - & NP \\
\hline antr-T3 & $T 199$ & G2a & ++ & - & $N P$ \\
\hline \multicolumn{6}{|l|}{ TCR } \\
\hline BMA031 & 479, T110 & $\mathrm{G} 2 \mathrm{~b}$ & ++ & - & NP \\
\hline BMA032 & 480 & G2b & ++ & - & NP \\
\hline WT31 & ref. 21 & $\mathrm{G} 1$ & ++ & - & ND \\
\hline TCR $\delta 1$ & ref 24 & $\mathrm{G} 1$ & $++^{a}$ & - & ND \\
\hline$T C R_{\gamma} / \delta 1$ & ref 25 & G1 & $++^{a}$ & - & ND \\
\hline Clonotypes & T105-109 & G2a & \pm & - & ND \\
\hline
\end{tabular}

The indicated TCR - CD3-specific mAb panel was assayed for surface immunofluorescence in $\mathrm{CD} 3 \epsilon$ transgenic mice or human peripheral blood T cells (PBL) $(++$, bnght; + , dull; and - , negatrve staining) and immunoprecipitation of recombinant soluble $\mathrm{CD} 3 \epsilon$ molecules $(\epsilon-x)$ ( + , precipitates; - , does not precipitate $\epsilon-x$ but precipitates membrane CD3, NP, farls to preciptate membrane CD3; ND, not tested).

aTCR $\delta$-specific antibodies stann brightly only a mınor subset of PBL.

However, none of the 12 remaining mAbs, which staned $\epsilon$-transgenic T cells, precipitated $\boldsymbol{\gamma} \cdot \boldsymbol{x}, \delta \cdot \boldsymbol{x}$, or $\epsilon-\boldsymbol{x}$, despite their ability to precipitate CD3 from T cells (e.g. Fig. 2, track 8; Table 1).

The data from the transgenic mouse and recombinant $\mathrm{CD} 3$ studies define a minimum of three groups of CD3-specific mAbs, 
a

\section{4}
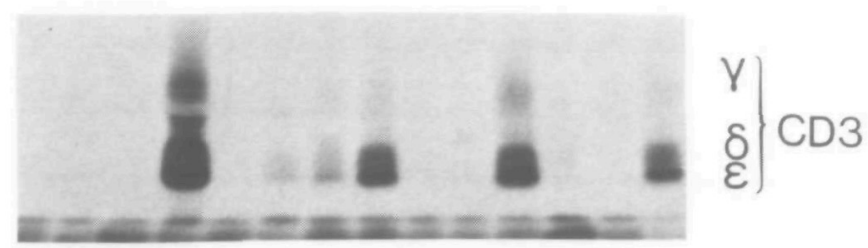

b
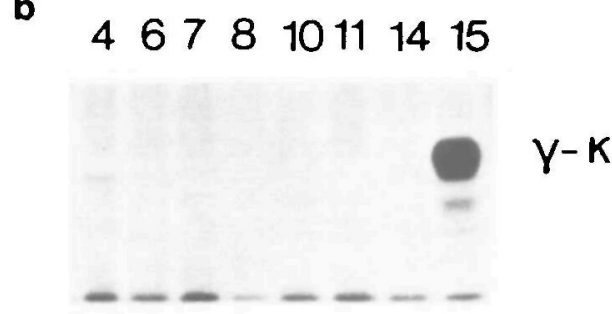

c

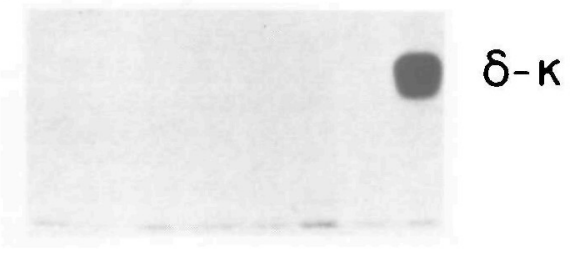

d

Fig. 2. Immunoprecipitation of native $\mathrm{CD} 3$ and recombınant $\mathrm{CD} 3 x$ molecules by monoclonal CD3-specific antibodies. (a) lodinated CD3 precipitated from surface-labelled human $T$ cells by monoclonal antibodies. Lanes 1, BL-A8; 2, 12F6; 3, T10/B9; 4, MEM-57, 5, MEM-92; 6. OKT3D; 7, F111-409; 8, YTH12.5, 9, М-T301, 10, М-T302; 11 , CD3.4B5, 12, SMC2; 13, 'ant1-T3', 14, UCHT1. (b-d) Metabolically labelled $\boldsymbol{\gamma} \cdot \boldsymbol{x}, \delta-\boldsymbol{x}$, and $\epsilon-\boldsymbol{x}$ respectively, precipitated by monocional antibodies functional in $\mathrm{Fig} \mathrm{2a}$, numbered identically. Lane 15 is a polyclonal rabbit anti-mouse $x$ serum. lodination of T cells (either Jurkat or a CD3 + T cell clone) by the lactoperoxidase method and subsequent Immunoprecipttation were adapted from Kaufman $\theta t$ al. (28). Cells were metabolically labelled for $4 \mathrm{~h}$ with $1 \mathrm{mCi}\left[{ }^{35}\right.$ S]methionıne after $1 \mathrm{~h}$ preincubation in methionine-free medium (Amımed, Based, Switzerland). Immune complexes were first resuspended in RIPA (1\% sodium deoxycholate, $0.1 \%$ sodium dodecyl sulphate, $150 \mathrm{mM} \mathrm{NaCl}, 50 \mathrm{mM}$ Trs - HCl, pH 7.4) and washed in NET-NON (O $5 \%$ Nonidet P. $40,5 \mathrm{mM}$ EDTA, $150 \mathrm{mM} \mathrm{NaCl}, 50 \mathrm{mM}$ Trıs $-\mathrm{HCl}, \mathrm{pH} 8,005 \%$ sodium azide), followed by a PBS wash before electrophoresis. Antibody $12 \mathrm{~F} 6$ gave variable results" while in the expenment shown it failed to preciptate natve CD3, other experıments were positive

and therefore of corresponding epitopes (Table 1): group I, which recognize $\mathrm{CD} 3 \epsilon$, since they immunoprecipitate $\epsilon-x$ and stain $\epsilon$-transgenic T cells brightly; group II, which stain $\epsilon$-transgenic $T$ cells but do not recognıze $\epsilon^{-\boldsymbol{x}}$; and group III, which do not bind
Table 2. Effect of TCR-CD3-specific mAbs on the proliferation of human $T$ cells

\begin{tabular}{|c|c|c|}
\hline \multirow[t]{2}{*}{ mAb coated } & \multicolumn{2}{|c|}{$\left[{ }^{3} \mathrm{H}\right]$ thymidine uptake $\left(\mathrm{c} p \mathrm{~m} . \times 10^{-3}\right)$} \\
\hline & $\overline{\mathrm{PBM}}$ & PBT \\
\hline \multicolumn{3}{|l|}{ Group I } \\
\hline UCHT1 & 47 & 35 \\
\hline Leu4 & 68 & 46 \\
\hline \multicolumn{3}{|l|}{ Group II } \\
\hline BMA030 & 31 & ND \\
\hline TR-66 & 44 & ND \\
\hline OKT3 & 70 & 58 \\
\hline T3/RW2-8C8 & 61 & 50 \\
\hline XIII-141 & 39 & 34 \\
\hline \multicolumn{3}{|l|}{ Group III } \\
\hline T3/2T8-2F4 & 24 & 20 \\
\hline BL-A8 & 30 & ND \\
\hline M-T302 & 53 & 47 \\
\hline \multicolumn{3}{|l|}{ TCR } \\
\hline BMA032 & 67 & 65 \\
\hline WT31 & 32 & 25 \\
\hline \multicolumn{3}{|l|}{ Control } \\
\hline CD2 (OKT11) & 0.5 & 07 \\
\hline CD5 (Leu-1) & 1 & 08 \\
\hline PBS & 07 & 0.5 \\
\hline
\end{tabular}

For proliferation assays, human peripheral blood mononuclear (PBM) cells or T cells (PBT) purified using nylon wool columns $(26)\left(2 \times 10^{5}\right.$ cells/well) were cultured in flat-bottomed 96 -well microtitre plates in complete medium supplemented with antibodies in the indicated combinations The mAbs ( $100 \mathrm{ng} /$ well) were directly bound to the plastic surface of the wells via a second step goat anti-mouse $\mathrm{lg}$ antiserum (Southern Bıotechnology, BIrmıngham, AL, USA), as described etsewtere (26). Wells were pulsed with $1 \mu \mathrm{Cl}\left[{ }^{3} \mathrm{H}\right]$ methylthymidine for the last $9 \mathrm{~h}$ of a 4-day culture penod and the radioactivity incorporated into the cells was estimated using a $\beta$-counter $\mathrm{ND}$, not tested

$\epsilon$-transgenıc T cells or recombinant CD3 polypeptides but can bind well to human $T$ cells

Solid-phase mAbs from all 3 groups, as well as TCR $\alpha \beta$-specific $m A b s$, were able to trigger human peripheral blood mononuclear or purified T cells in a proliferation assay (Table 2). It is therefore clear that a mitogenıc stımulus can be delivered through a number of different epitopes on the TCR-CD3 complex.

In summary, it has been demonstrated that most CD3 epitopes (>80\%) can be conferred by the human CD3 $\epsilon$ chain when incorporated into a mouse TCR-CD3 complex. One-third of these epitopes (defined by group I mAbs) could also be seen on recombinant $\boldsymbol{\epsilon - \boldsymbol { x }}$, which unambiguously maps their positıon within the native receptor. The group II mAbs, which do not bind $\epsilon-\boldsymbol{x}$ but staın positively $\epsilon$-transgenic T cells, may be recognizing conformational determınants which rely on association of CD3 $\epsilon$ with other subunits in the complex for their formation. In this regard, the variable intensity of stainıng of $\epsilon$-transgenic T cells by group II mAbs may be explained by how well assemblydependent epitopes conferred by $\mathrm{CD} 3 \epsilon$ are formed in the chimaeric mouse/human TCR-CD3 complex. A proportion (7/36) of the antibody panel (group III) did not appear to recognize epitopes conferred by $\mathrm{CD} 3 \epsilon$, at least in association with mouse TCR - CD3 subunits. These mAbs may require the presence of other human polypeptides for bınding. 
Other workers have previously shown by Western blottıng that some of the group I mAbs identify CD3e (15). They also demonstrated that these mAbs function in cytoplasmıc immunofluorescent stainıng experiments, whereas group II and (group III) $\mathrm{mAbs}$ show no CD3-specific reactivity with either technıque (15). Such epitopes are apparently not found either on individual CD3 chans or intracellular CD3 complexes. This further suggests that many group II mAbs may be recognizing conformational epitopes, dependent on the assembly of the whole TCR - CD3 complex. In the case of the F101.01 mAb, evidence has been presented in support of this (16).

That the majority of CD3-specific mAbs recognize epıtopes Involving $\mathrm{CD} 3 \epsilon$ (directly or indirectly) is probably a reflection of the ımmunodominance of this subunit Strıkıngly, the differences between the $\mathrm{N}$-termınal sequences of human and mouse $\mathrm{CD} 3 \mathrm{\epsilon}$ seem to be clustered, a phenomenon not seen for the CD3 $\gamma$ or $-\delta$ chains, where sequence differences are more randomly distributed (17). These patches of sequence disparity may account for the strong mouse anti-human CD3e Immune response. Interestıngly, two hamster anti-mouse $\mathrm{CD} 3 \mathrm{mAbs}$ also recognize the $\mathrm{CD} 3 \epsilon$ chain $(13,18)$. The bias of CD3-specric mAbs to $\mathrm{CD} 3 \epsilon$ should temper the conclusions reached using such mAbs in tests for the presence of the CD3 complex as a whole, for example, in developmental studies. New mAbs are currently being developed using soluble $\mathrm{CD} 3 \gamma$ and $-\delta$ as immunogens which will allow a more accurate assessment of the expression and function of the individual CD3 components in a given cell type.

Functional studies showed that CD3-specific mAbs in each group, as well as TCR $\alpha \beta$-specific mAbs, can promote proliferation of human $T$ cells and therefore that $T$ cell activation by receptor-binding mAbs can proceed through several, and possibly multuple, epitopes. This raises doubts about the existence of particular 'functional' epitopes on the CD3 complex, perturbation of which is responsible for activation. Rather, it suggests that the cross-Inking function of mitogenic mAbs may be their most significant property. Indeed, monovalent CD3-specific mAbs do not seem to trigger $T$ cells unless they are cross-linked or bridged to a second cell (19). Furthermore, despite several attempts to define functional epitopes on the TCR - CD3 complex (4), we have been unable to correlate the functional mAb groupıngs of other authors with those defined here. This suggests that the properties of indıvidual antibodies, such as avidity and isotype, may have to be taken into account in such studies

\section{Acknowledgements}

We would like to thank Professor A McMichael, Drs P. Rieber, P. Beverley, J. A Bluestone, J. Borst, M B Brenner, J E. de Vries, A. Lanzavecchia, T. Plesner, E. Roosnek, W. Tax, and R. van Lter for mAbs; Drs $E$ Roosnek, R. Palacios, and $G$. de Libero for critical reading of the manuscript; Mr U. Müller for production of transgenic mice; and Miss K. Zürcher for excellent preparation of the typescript The Basel Institute for Immunology was founded and is supported by $F$ Hoffmann-La Roche \& Co. Ltd, Basel. A.H. is on leave of absence from the Instituto de Investıgaciones Biologicas, CSIC, Madrut

\section{Abbreviations}

$\begin{array}{ll}\text { FACS } & \text { fluorescence-activated cell sorter } \\ \text { mAb } & \text { monoclonal antibody } \\ \text { PBS } & \text { phosphate-buffered saline } \\ \text { TCR } & T \text { cell receptor for antigen }\end{array}$

\section{References}

1 Chang, T. W, Kung, P.C., Gingras, S.P , and Goldstern, G 1981 Does OKT3 monoclonal antibody react with an antigen-recognition structure on human T cells? Proc. Natl Acad. ScI USA 78.1805.

2 Reinherz, E L., Meuer, S., Fitzgerald, K A, Hussey, R E., Levine, $H$, and Schlossman, S. F. 1982. Antigen recognition by human T lymphocytes is linked to surface expression of the T3 molecular complex. Cell 30.735

3 van Wauwe, J. P., De Mey, J R, and Goossens, J. G. 1980 OKT3. a monoctonal anti-human T lymphocyte antibody with potent mitogenic properties. J. Immunol 124.2708 .

4 McMichael, A J. et al., eds. 1987 Leucocyte Typing III Oxford University Press, Oxford.

5 van Lier, R A W., Boot, J H A., Verhoeven, A. J., de Groot, E. R, Brouwer, $M$. and Aarden, $L$ A. 1987. Functional studies with antiCD3 heavy chain isotype switch variant monoclonal antibodies Accessory cell-independent induction of interleukin 2 responsiveness in T cells by $\epsilon$-anti-CD3. J. Immunot. 1392873

6 Roosnek, E., van Lier, R. A., and Aarden, L. A. 1987. Two monoclonal antl-CD3 antibodies can induce different events in human $T$ lymphocyte activation Eur J Immunol. 17.1507

7 van Lier, R. A. W. Boot, J. H A., de Groot, E. R., and Aarden, L. A. 1987 Induction of T cell prolferation whth anti-CD3 switch-variant monoclonal antibodies. effects of heavy chain isotype in monocytedependent systems. Eur J. Immunot 17:1599.

8 Clark, E A, Martin, P. J., Hansen, J. A., and Ledbetter, J A 1983. Evolution of eprtopes on human and non-human pnmate lymphocyte cell surface antigens. Immunogenetics 18599

9 Brochier, J. and Schmitt, D. 1984 Cross-reactivity of anti-lymphocyte monoclonal antibodies on human skın components. In Reinherz, E. $\mathrm{L}$ et al, eds Leucocyte Typing II, Vol. 1, p. 407 Springer Verlag, Now York.

10 Hansen, J. A, Martin, P J , Beatty, P. G , Clark, E. A., and Ledbetter, J A. 1984. Human T lymphocyte cell surface molecules defined by the workshop monoclonal antibodies ('T cell protocol'). In Bernard, A., Boumsell, L, Dausset, J., Milsteın, C., and Schlossman, S. F , eds, Leucocyte Typing, p. 195 Springer Verlag, Berlin.

11 Kurrle, R, Seyfert, W. Trautwen, A., and Seller, F R. 1985. Cellular mechanisms of $T$ cell activation by modulation of the T3 antigen complex. Transplant Proc. 17880

12 Wallace, D. L., Macintyre, E A., Linch, D. C., and Beverley, P. C L. 1987. Analysis of the activation signals induced by CD3 antibodies and their role in T-cell proliferation. In McMichael, $A \mathrm{~J}$ et al., eds, Leucocye Typing III, p. 167. Oxford University Press, Oxford

13 Leo, O., Foo, M., Sachs, D H., Sametson, L E, and Bluestone, J. A. 1987. Identification of a monoclonal antibody specific for a murine T3 polypeptide. Proc. Natl. Acad. SCI. USA 84:1374.

14 Tunnacliffe, A., Olsson, C , Traunecker, A., Krissansen, G W., and Karjalanen, K. 1989. Production and secretion of recombinant sołuble CD3 pofypeptides by myeloma-derived transfectant clones Immunol. Lett. 21243

15 van Dongen, J. J. M., Krissansen, G. W. Wolvers-Tettero, I. L. M., Comans-Bitter, W.M., Adriaansen, H. J., Hooıkaas, H , van Werıng, E R., and Terhorst, C. 1988 Cytoplasmic expression of the CD3 antigen as a diagnostic marker for Immature T-cell malignancies. Blood 71.603

16 Geister, C., Plesner, T, Pallesen, G., Skpdt, K., $D$ dum, N., and Larsen, J. K. 1988. Characterisation and expression of the human T cell receptor - T3 complex by monoclonal antibody F101.01. Scand $J$. Immunol. 27.685.

17 Clevers, H., Alarcon, B., Wileman, T, and Terhorst, C. 1988. The T cell receptor/CD3 complex. a dynamic protein ensemble. Annu. Rev. Immunol. 6.629.

18 Havran, W. L., Poenie, M., Kımura, J., Tsien, R., Weiss, A., and Allison, J.P. 1987. Expression and function of the CD3-antigen receptor on murine CD4+8+ thymocytes Nature 330:170.

19 Roosnek, E. and Lanzavecchia, A. 1989. Triggering T cells by otherwse inert hybnd anti-CD3/ant-tumor antibodies requires encounter with the specific target cell. J. Exp. Med. 170:297.

20 Lanzavecchia, A. and Scheldegger, D. 1987. The use of hybrid hybndomas to target human cytotoxic T lymphocytes. Eur. J. Immund. 17.105 . 
21 Tax, W. J. M., Willems, H W., Reekers, P. P M, Capel, P. J A, and Koene, R. A. P. 1983. Polymorphism in mitogenic effect of IgG1 monoclonal antibodies against T3 antigen on human T cells Nature $304 \cdot 445$.

22 Kung, P.C, Goldsteın, G., Reinherz, E L., and Schlossman, S. F 1979. Monoclonal antibodies defining distinctive human T cell surface antigens Science 206.347.

23 Spits, H. Keizer, G., Borst, J., Terhorst, C., Hekman, A , and de Vnes, $\mathrm{J}$ E. 1983. Characterization of monoclonal antibodies against cell surface molecules associated with cytotoxic activity of natural and activated killer cells and cloned CTL lines. Hybndoma 2:423

24 Band, H., Hostenbach, F., McLean, J, Hata, S., Krangel, M. S, and Brenner, M. B. 1987 Immunochemical proof that a novel rearranging gene encodes the $T$ cell receptor $\delta$ subunit. Science 238.682.

25 Borst, J., Van Dongen, J. J. M. Bolhuls, R L.H., Peters, P J, and van de Griend, R. J. 1988. Distinct molecular forms of human T cell receptor $\gamma \delta$ detected on viable T cells by a monoclonal antibody $J$ Exp. Med 167'1625
26 Carrera, A. C., Rincon, M., Sanchez-Madrid, F., Lopez-Botet, M , and O. de Landazuri, M. 1988 Triggerıng of co-mitogenic signals in T cell proliferation by anti-LFA-1 (CD18, CD11a), LFA-3 and CD7 monoclonal antibodies. J. Immunol. 141.1919.

27 Tonbo, M.L., de la Hera, A., Borst, J, Marcos, M. A R., Marquez, C., Alonso, J M . Barcena, A., and Martinez-A., C 1988. Involvement of the interleukin 2 pathway in the rearrangement and expression of both $\alpha \beta$ and $\gamma \delta$ cell receptor genes in human T cell precursors $J$ Exp. Mod. 168.2231

28 Kaufman, J F. Flajnik, M. F., du Pasquer, L., and Tiegert, P 1985 Xenopus MHC class II molecules. I. Identrfication and structural characterisation $J$ Immunol $134 \cdot 3248$

\section{Note added in proof}

Some similar data to those described in this article have been presented by Transy ot al 1989 Eur. J. Immund 19.947 